\title{
PENGARUH LAYANAN BIMBINGAN KELOMPOK TEKNIK DISKUSITERHADAP SIKAP TOLERANSI DALAM KEBERAGAMAN BUDAYA DENGAN TEMAN SEBAYA PADA SISWAKELAS VIII SMP SWASTA PELITA MEDANTAHUN AJARAN 2018/2019
}

\author{
Ingrid Abdillah Simanjuntak \\ Zuraida Lubis, M.Pd Kons \\ Program Studi Bimbingan dan Konseling Universitas Negeri Medan
}

\begin{abstract}
Abstrak
Tujuan penelitian ini adalah untuk mengetahui pengaruh layanan bimbingan kelompok teknik diskusi terhadap sikap toleransi dalam keberagaman budaya dengan teman sebaya pada siswa kelas VIII SMP Swasta Pelita Medan Tahun Ajaran 2018/2019.Metode yang digunakan dalam penelitian ini adalah metode kuantitatif.Jenis penelitian ini adalah quasi experiment dengan one group pretest dan post-test design.Subjek dalam penelitian ini adalah siswa kelas VIII yang terdiri dari 10 orang siswa.Instrument yang digunakan adalah angket untuk mengetahui sikap toleransi dalam keberagaman budaya.Teknik analisis data dengan Uji Wilcoxon.Hasil analisis data yang diperoleh dalam penelitian ini adalah dengan perhitungan skor test awal (Pre-Test) diperoleh rata-rata 59,8 termasuk kategori rendah sedangkan (Post-Test) atau setelah pemberian layanan bimbingan kelompok teknik diskusi diperoleh skor rata-rata 90,3 termasuk kategori tinggi. Artinya rata-rata skor sikap toleransi dalam keberagaman budaya lebih tinggi sesudah mendapatkan layanan bimbingan kelompok teknik diskusi. Perubahan peningkatan sikap toleransi dalam keberagaman budaya dengan teman sebaya setelah diberi layanan bimbingan kelompok teknik diskusi sebesar $51,00 \%$. Dengan nilai $\mathrm{J}_{\text {hitung }}=19, \alpha=0,05$ dan $\mathrm{N}=10$ maka berdasarkan daftar, $\mathrm{J}_{\text {tabel }}=8$. Didapatkan $\mathrm{J}_{\text {hitung }}>\mathrm{J}$ tabel dengan penjelasan $(19>8)$. Hal ini berarti hipotesis yang berbunyi ada pengaruh Layanan Bimbingan Kelompok Teknik Diskusi Terhadap Sikap Toleransi Dalam Keberagaman Budaya Dengan Teman Sebaya Pada Siswa Kelas VIII SMP Swasta Pelita Medan T.A 2018/2019 dapat diterima.
\end{abstract}

Kata Kunci: Bimbingan Kelompok; Diskusi; Toleransi; Keberagaman Budaya

\section{PENDAHULUAN}

Indonesia merupakan negara dengan kultur budaya dan sosial yang sangat beragam. Berbagai suku, budaya, agama, ras, dan cara berperilaku dalam bersosialisasi mewarnai kehidupan bertoleransi di negara Indonesia. Dengan keanekaragaman budaya yang di miliki oleh berbagai daerah di Indonesia membuat masyarakat harus memiliki sikap toleransi yang tinggi.

Masyarakat yang hidup dalam suatu negara yang beranekaragam budaya tentu bukanlah persoalan yang
mudah.Banyak konflik sosial yang dilatarbelakangi oleh faktor-faktor etnis, budaya dan agama yang selalu datang silih berganti, sambung-menyambung, seolah-olah tak berpenghujung dan berketepian. Akan tetapi semua itu dapat kita atasi, jika setiap warga negara menyadari akan pentingnya hidup bersama dengan dilandasi oleh sikap toleransi dalam keberagaman budaya yang dimiliki masing-masing individu.

Dalam hal ini sikap toleransi tentang keberagaman budaya menjadi pembahasan yang sangat menarik untuk 
diteliti.Dengan artian, peneliti masih menemukan masalah siswa yang berkaitan sikap toleransi dalam keberagaman budaya yang dimiliki oleh teman sebayanya di sekolah.Siswa masih belum mengetahui keberagaman budaya yang mereka miliki merupakan suatu hal yang unik.

Toleransi yang penulis batasi di sini pada hakikatnya merupakan sikap tenggang rasa sesama manusia.Sikap dasar itulah yang menjadi kesediaan untuk menerima, menghargai dan menghormati sebagai insan yang memiliki kelebihan dan kekurangan baik itu pada perbedaan suku, budaya, dan pendapat. Toleransi juga harus menunjukkan sikap saling menghormati keyakinan dan pendapat yang dimiliki oleh orang lain. Dalam arti tidak merusak, tidak memaksakan orang lain harus sesuai dengan apa yang kita mau, dan tidak menjatuhkan satu sama lain.

Berdasarkan hasil observasi dan analisis angket yang penulis lakukan di SMP Swasta Pelita Medan kepada seluruh siswa kelas VIII berjumlah 34 siswa, menunjukkan bahwa presentase masalah yang berkaitan dengan sikap toleransi yaitu: siswa tidak dapat menerima teman yang berbeda pendapat, budaya ataupun bahasa (57\%), siswa tidak dapat menerima kekurangan/kelemahan orang lain baik fisik ataupun perbedaan budaya (43\%).

Bimbingan kelompok teknik diskusi adalah layanan bimbingan dan konseling yang dilakukan oleh sekelompok orang (peserta didik) dengan cara berdiskusi memanfaatkan dinamika kelompok untuk memperoleh berbagai bahan dari narasumber tertentu (terutama dari guru pembimbing) dengan membahas secara bersama-sama pokok bahasan (topik) tertentu guna mengeluarkan pendapat, memberikan tanggapan, saran, dan sebagainya.

Untuk itu, penulis dapat melakukan bimbingan kelompok teknik diskusi yang diharapkan bisa membantu menyediakan informasi-informasi bermanfaat untuk mencapai perkembangan yang optimal.Baik sebagai individu maupun sebagai pelajar untuk pertimbangan dalam mengambil keputusan dan tindakan yang tertentu.

Dengan demikian, melalui pelaksanaan bimbingan kelompok teknik diskusi siswa dapat menyatakan pendapatnya dan saling bertukar pikiran mengenai sikap toleransi dalam keberagaman budaya dengan teman sebaya. Mengetahui apa saja keuntungan yang didapat dengan saling menghargai pendapat satu sama lain tanpa membatasi 
diri dengan adanya perbedaan pendapat, suku maupun budaya.

\section{KAJIAN PUSTAKA}

\section{Sikap}

Menurut Gerungan (2004: 161) menjelaskan bahwa "sikap merupakan kecenderungan untuk bertindak sesuai dengan sikap objek tersebut atau lebih tepatnya kesediaan untuk beraksi terhadap suatu hal".

Sarwono (2003: 233) menyatakan bahwa: "Sikap adalah sesuatu hal yang mengarahkan perilaku dan memiliki unsur penilaian terhadap objek sikap, serta lebih dapat dibentuk, dikembangkan, dipengaruhi, dan diubah".

Dari beberapa pengertian di atas dapat disimpulkan bahwa sikap merupakan reaksi yang ditujukan pada objek tertentu yang sedang dihadapi.

Azwar

menyimpulkan bahwa faktor-faktor yang mempengaruhi pembentukan sikap adalah pengalaman pribadi, kebudayaan, orang lain yang dianggap panting, media massa, institusi atau lembaga agama, serta faktor emosi dalam diri individu.

\section{Toleransi}

Toleransi menurut Kamus Besar Bahasa Indonesia ialah "bersifat atau bersikap menenggang (menghargai, membiarkan, memperbolehkan) pendirian (pendapat, pandangan, kepercayaan, kebiasaan, kelakuan dan sebagainya) yang berbeda atau bertentangan dengan pendirian sendiri”.

Toleransi yakni sikap dan perilaku yang mencerminkan penghargaan terhadap perbedaan, aliran kepercayaan suku, adat, bahasa, etnis, pendapat, dan hal-hal lain yang berbeda dengan dirinya secara sadar dan terbuka, serta dapat hidup tenang di tengah perbedaan tersebut (Suyadi, 2013: 8).

Wibowo (2011: 43) "toleransi adalah sikap dan tindakan yang menghargai perbedaan agama, suku, etnis, pendapat, sikap dan tindakan orang lain yang berbeda dari dirinya".

Menurut Marzuki (2014: 59) "toleransi membuat anak mampu menghargai perbedaan kualitas dalam diri orang lain, membuka diri terhadap pandangan dan keyakinan baru, serta menghargai orang lain tanpa membedakan suku, gender, penampilan, budaya, agama, kepercayaan, kemampuan, atau orientasi seksual”.

Sedangkan menurut Darwati, dkk (2014) toleransi secara luas adalah suatu perilaku manusia yang tidak menyimpang dari aturan, dimana seseorang menghargai atau menghormati setiap tindakan yang orang lain lakukan.

Dari beberapa pengertian di atas, maka dapat penulis simpulkan bahwa 
toleransi adalah sikap dalam menghargai perbedaan budaya, suku, agama, dan pendapat orang lain yang berbeda darinya dengan hidup tenang ditengah perbedaan tersebut.

\section{Aspek-Aspek Toleransi}

Toleransi dimaknai sebagai apresiasi terhadap kebinekaan atau keberagam. Raka (dalam penelitian Astri, 2015) memberikan indikator terhadap karakter toleransi yang dikategorikan kedalam beberapa aspek-aspek toleransi yaitu :

1. Bisa menghargai pendapat atau budaya yang berbeda.

2. Bisa menjaga lisan dan prasangka dalam berkomunikasi.

3. Bisa menjalin hubungan sosial atau berinteraksi dengan teman sebaya dari berbagai latar belakang budaya.

4. Tidak mendominasi atau ingin menang sendiri.

\section{Bimbingan Kelompok}

Winkel \& Sri Hastuti (2004: 547) mengemukakan "bimbingan kelompok adalah kegiatan kelompok diskusi yang menunjang perkembangan pribadi dan parkembangan sosial masing-masing individu-individu dalam kelompok, serta meningkatkan mutu kerja sama dalam kelompok untuk menunjang perkembangan optimal masing-masing siswa yang diharapkan dapat mengambil manfaat dan pengalaman pandidikan ini bagi dirinya sendiri".

$$
\text { Tohirin (2007: 170) }
$$

mengemukakan "bimbingan kelompok merupakan suatu cara memberikan bantuan (bimbingan) kepada individu (siswa) melalui kegiatan kelompok". Dalam layanan bimbingan kelompok, aktivitas dan dinamika kelompok harus diwujudkan untuk membahas berbagai hal yang berguna bagi pengembangan atau pemecahan masalah individu ( siswa ) yang menjadi peserta layanan”.

Dari berberapa pengertian bimbingan kelompok di atas, maka dapat disimpulkan bahwa bimbingan kelompok adalah suatu kegiatan kelompok yang dilakukan oleh sekelompok orang dengan memanfaatkan dinamika kelompok yaitu adanya interaksi saling mengeluarkan pendapat, memberikan tanggapan, saran dan sebagainya, dimana pemimpin kelompok menyediakan informasiinformasi yang bermanfaat.

\section{Teknik Diskusi}

$$
\text { Tohirin }
$$

mengemukakan bahwa diskusi kelompok merupakan suatu cara siswa memperoleh kesempatan untuk memecahkan masalah secara bersama-sama. Setiap siswa memperoleh kesempatan untuk 
mengemukakan suatu masalah. Roestiyah (2012:5) menyatakan bahwa "Di dalam diskusi ini proses interaksi antara dua atau lebih individu yang terlibat, informasi memecahkan masalah dapat terjadi juga semuanya aktif tidak ada yang pasif sebagai pendengar saja”.

Dapat disimpulkan bahwa diskusi kelompok adalah suatu cara yang dilakukan masing-masing anggota kelompok untuk menyampaikan pemikirannya dalam kelompok guna mendapatkan suatu kesimpulan dan bahan yang sedang dibahas dan menghasilkan sebuah keputusan yang akan disepakati oleh anggota kelompok.

\section{METODE PENELITIAN}

Adapun jenis dari penelitian ini adalah penelitian eksperimen semu (quasi experimental design) yaitu penelitian yang memberikan perlakuan kepada sekelompok orang yang dijadikan subjek penelitian. Menurut Arikunto (2010: 123) eksperimen adalah suatu cara untuk mencari hubungan sebab akibat (kausal) antara dua faktor-faktor lain yang mengganggu. Eksperimen dilakukan dengan maksud untuk melihat suatu perlakuan.

Lokasi penelitian dilakukan di SMP Swasta Pelita Medan, yang berlokasi di Jalan Suasa Seletan Psr. III
Kelurahan Mabar Hilir, Kecamatan Medan Deli, Kota Medan.

Populasi dari penelitian ini adalah 34 siswa kelas VIII SMP Swasta Pelita Medan tahun ajaran 2018/2019.Dengan berdasarkan hasil instrumen yang memiliki skor paling rendah, maka dipilih 10 orang dengan budaya dan agama berbeda untuk diberikan layanan bimbingan kelompok atau dijadikan sebagai sampel penelitian.

Desain yang digunakan dalam penelitian ini adalah desain pre-test dan post-test group dengan polanya sebagai berikut :

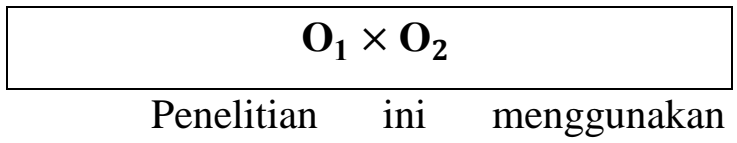
teknik analisis data dengan uji Wilcoxon yaitu dengan mencari perbedaan mean pretest dan posttest.Analisis ini digunakan untuk mengetahui apakah ada pengaruh layanan Bimbingan Kelompok teknik diskusi terhadap sikap toleransi dalam keberagaman budaya dengan temn sebaya pada siswa kelas VIII SMP Swasta Pelita Medan.

\section{HASIL PENELITIAN}

Pada hasil penelitian ini diketahuai bahwa, hipotesis penelitian diterima, artinya terdapat pengaruh dari Layanan Bimbingan Kelompok Teknik Diskusi Terhadap Sikap Toleransi Dalam Keberagaman Budaya Dengan 
Teman Sebaya Pada Siswa Kelas VIII SMP Swasta Pelita Medan Tahun Ajaran 2018/2019. Hal ini telah ditunjukkan dari hasil perhitungan Uji Wilcoxon yaitu $\mathrm{J}_{\text {hitung }}>\mathrm{J}_{\text {tabel }}$ Dengan perolehan $(19>8)$.

Dengan jumlah skor Pre-Test sebesar 598, nilai tertinggi skor Pre-Test 70, nilai terendah skor Pre-Test 56,dan nilai rata-rataskor Pre-Test 59,8. Sedangkan jumlah skor Post-Test sebesar 903, nilai tertinggi skor Post-Test 106, nilai terendah skor Post-Test 90,dan nilai rata-rataskor Post-Test 90,3. Jumlah skor selisih perubahan sebesar 305, nilai tertinggi 47 , nilai terendah 5 dan rata-rata skor selisih 30,5. Lalu Persentase perubahan berjumlah $51 \%$, nilai tertinggi persentase $79 \%$, nilai terendah $8 \%$, dan nilai rata-rata persentase perubahan sebesar $51,00 \%$

Bila dilihat secara umum terjadi perubahan peningkatan toleransi dalam keberagaman budaya siswa disekolah. Dengan nilai secara keseluruhan pada 10 orang responden pada tes awal (Pre-Test) diperoleh skor rata-rata sikap toleransi dalam keberagaman budaya siswa diperoleh $=59,8$ dan setelah pemberian layanan Bimbingan Kelompok Teknik Diskusi $($ Post-Test $)$ diperoleh $=90,3$ artinya rata-rata skor sikap toleransi dalam keberagaman budaya lebih tinggi sesudah mendapatkan layanan Bimbingan Kelompok Teknik Diskusi, dan setelah diberikan layanan Bimbingan Kelompok Teknik Diskusi maka sikap toleransi dalam kebergaman budaya menjadi meningkat.

Namun demikian bila dilihat secara individual masih ditemukan siswa/ responden yang memiliki perubahan peningkatan yang rendah atau tidak begitu pesat menaik perubahannya yaitu SK dan SY. Dimana hasil Pre-Test SK memperoleh skor 62 dan hasil Post-Test SK memperoleh skor 67 maka selisih skor 5 point artinya hanya terjadi perubahan peningkatan sebesar $8 \%$. Hal ini disebabkan karena SK kurang serius selama mengikuti layanan bimbingan kelompok teknik diskusi.

Selain itu SY juga memperoleh hasil skor yang tidak begitu pesat menaik perubahannya dengan hasil Pre-Test SY memperoleh skor 70 dan Post-Test memperoleh skor 76 maka selisih skor berjumlah 6 point artinya hanya terjadi perubahan peningkatan sebesar $8 \%$. Hal ini disebabkan karena SY merasa bahwa hubungan sosial atau sikap toleransinya telah baik dengan teman sebayanya yang beragam budaya.

Sedangkan kedelapan responden lainnya merasakan dampak baik jika mereka memiliki sikap toleransi dalam 
keberagaman budaya maupun agama yang dimiliki teman sebayanya.Siswa dapat berfikir dengan dimilikinya sikap toleransi dalam keberagaman budaya maupun agama dari teman sebayanya, mereka dapat menciptakan hubungan pertemanan maupun persahabatan dengan semua teman tanpa memikirkan perbedaan yang mereka miliki.

Dengan Bimbingan Kelompok Teknik Diskusi ini menjadi jalan untuk terbinanya sikap toleransi dalam keberagaman budaya yang dimiliki oleh teman sebayanya pada kelas VIII SMP Swasta Pelita Medan. Dengan layanan bimbingan kelompok teknik diskusi inilah penulis meningkat sikap toleransi siswa dalam keberagaman budaya agar tidak menganggap beda budaya itu sesuatu yang wajib dijauhi dan tidak layak untuk menjadi temannya.

Melalui strategi pemberian layanan Bimbingan Kelompok Teknik Diskusi ini, disamping peserta didik dapat berani mengeluarkan pendapat dengan teman sebayanya juga dapat menggunakan pengetahuan dan pengalamannya untuk pembahasan masalah yang dibahas, tanpa selalu bergantung pada pendapat orang lain.

Hal tersebut dapat ditinjau dari hasil laiseg pada setiap pertemuan ditemukan bahwa anggota kelompok sudah memiliki peningkatan cara berfikir, merasa, bersikap, bertindak dan bertanggung jawab yang baik terhadap sikap toleransi dalam keberagaman budaya yang dimiliki oleh teman sebayanya. Dengan demikian terlihat komitmen siswa dalam meningkatkan sikap saling menghargai dari perbedaan yang ada dalam hubungan pertemanan dan dibuktikan dari hasil angket PostTest yang diberikan peneliti menunjukkan peningkatan sikap toleransi dalam keberagaman budaya dengan teman sebaya.

\section{PENUTUP}

\section{Kesimpulan}

Hasil analisis data yang diperoleh dalam penelitian ini yaitu dapat dilihat dari nilai $\mathrm{J}_{\text {hitung }}=19$ dengan $\alpha=0,05$ dan $\mathrm{N}=10$. Maka berdasarkan pengujian dua arah $\mathrm{J}_{\text {tabel }}=8$, dari data tersebut terlihat bahwa $\mathrm{J}_{\text {hitung }}>\mathrm{J}_{\text {tabel }}$ dengan penjelasan $(19>8)$. Artinya hipotesis diterima.

Data Pre-Test diperoleh rata-rata 59,8 sedangkan data Post-Test setelah diberikan layanan bimbingan kelompok teknik diskusi diperoleh rata-rata sebesar 90,3 .

Artinya skor rata-rata siswa setelah diberikan layanan bimbingan kelompok teknik diskusi meningkat daripada sebelum diberikan layanan 
bimbingan kelompok teknik diskusi sebesar $51 \%$.

Hal ini menunjukkan terdapat Pengaruh Layanan Bimbingan Kelompok Teknik Diskusi Terhadap Sikap Toleransi Dalam Keberagaman Budaya dengan Teman Sebaya Pada Siswa Kelas VIII SMP Swasta Pelita Medan Tahun Ajaran 2018/2019, maka dengan demikian hipotesis dapat diterima.

Kemudian dapat disimpulkan secara umum terjadi perubahan peningkatan pada 10 orang siswa namun terdapat 2 responden yang memiliki perubahan peningkatan yang masih rendah yaitu SK (8\%) dan SY $(8,5 \%)$.

\section{Saran}

Berdasarkan kesimpulan di atas, maka saran yang bisa dikemukakan peneliti dalam penelitian ini adalah:

Bagi pihak sekolah diharapkan agar memberikan fasilitas, sarana dan prasana untuk melakukan kegiatan bimbingan dan konseling di sekolah agar tujuan yang diharapkan dapat tercapai secara optimal.

Bagi guru BK kiranya dapat menggunakan teknik yang berbeda untuk menangani siswa yang bermasalah pada sikap toleransi dalam keberagaman budaya semisalnya menggunakan teknik individual/pendekatan khusus.
Bagi siswa/i diharapkan dapat meningkatkan sikap toleransi dalam keberagaman budaya dengan menjaga lisan ataupun ucapan saat berbicara dengan teman sebaya, orang tua, guru dan bertingkah laku sesuai Bhinneka Tunggal Ika agar tidak terjadi kesenjangan dari keberagaman budaya tersebut.

Bagi peneliti lain diharapkan dapat mempertimbangkan faktor-faktor penyebab siswa yang tidak mengalami perubahan peningkatan yang pesat seperti lebih memperhatikan keseriusan siswa mengikuti layanan khususnya dalam bimbingan kelompok teknik diskusi.

\section{DAFTAR PUSTAKA}

Arikunto, Suharsimi. 2010. Prosedur Penelitian Suatu Pendekatan Praktik. Jakarta: Rineka Cipta.

Azwar, Saifuddin. 2016. Sikap Manusia Teori dan Pengukurannya. Yogyakarta:

Pustaka Pelajar.

Darwati, K. E \& Suranata, K. (Eds).2014. Penerapan Konseling Rasional Emotif Dengan Teknik Modeling Untuk Meningkatkan Toleransi Antar Siswa Kelas XTKJ2 SMK Negeri 3 Singaraja. E-Journal Undiksa Jurusan Bimbingan Konseling, 2. 
Dayanti, Astri. 2015. Pengembangan Sikap Toleransi Terhadap Perbedaan Pendapat Siswa Melalui Discovery Learning Dalam Pembelajaran IPS (Penelitian Tindakan Kelas Terhadap Siswa Kelas VII-C SMP Negeri 44 Bandung).Skripsi.FPIPS.Pendidik an Ilmu Pengetahuan Sosial. Universitas Pendidikan Indonesia: Bandung.

Gerungan, W.A. 2004.Psikologi Sosisal.Bandung: Reflika Aditama

Hartina, Sitti. 2010. Konsep Dasar Bimbingan Kelompok. Bandung: Refika Aditiama.

Ismail, Radjiman. 2017. Meningkatkan Sikap Toleransi Siswa Melalui Pembelajaran Tematik (Penelitian Tindakan Pada Siswa Kelas III Sekolah Dasar di Wilayah Kecamatan Kota Ternate Utara.Jurnal Ilmiah Pendidikan Islam Anak Usia Dini. Volume 2 Nomor 1 Juni.ISSN 2086-6909.

Juntika, Achmad. 2005. Strategi Layanan Bimbingan \& Konseling. Bandung: PT. Refika Aditama.
Kansil, C. 1996. Pendidikan Pancasila dan Kewarganegaraan Jilid 1A Untuk SMU Kelas 1.Jakarta: Erlangga.

Marzuki. 2015. Pendidikan Karakter Islam. Jakarta : Amanah.

Nashir, Haedar. 2013. Pendidikan Karakter Berbasis Agama Dan Budaya. Yogyakarta: Multipresindo.

Nurnaningsih. 2011. Bimbinghan Kelompok Untuk Meningkatkan Kecerdasan Emosional Siswa. Jurnal Edisi Khusus No 1. ISSN 1412-565X.

Prayitno, 2004.Dasar-Dasar Bimbingan Konseling. Jakarta: Rineka Cipta.

Rifdah, Amanda. 2015. Keberagaman Budaya DI Indonesia (Online), dalam https://amandarifdah.wordpress.co $\mathrm{m} / 2015 / 09 / 24 /$ keberagamanbudaya-di-indonesia/ diakses pada 05 Maret 2018.

Sarwono, S.W. 2003. Psikologi Remaja. Jakarta: Rajawali Press.

Sutardi, Tedi. 2009. Antropologi Mengungkap Keragaman Budaya Untuk Kelas IX Sekolah Menengah Atas/Madrasah Aliyah Program 
Bahasa. Jakarta: Pusat Perbukuan, Departemen Pendidikan Nasional.

Suyadi. 2013. Strategi Pembelajaran Pendidikan Karakter. Bandung: PT. Remaja Rosdakarya.

Tohirin. 2007. Bimbingan Dan Konseling Disekolah Dan Madrasah (Berbasis Integrasi). Jakarta : PT Raja Grafindo Persada.

Wahyudi, Antonius. ( academiamail.com) 07 Maret 2018. Tema 1 Indahnya Kebersamaan Sub Tema 1 Keberagaman Budaya Bangsaku. Email Kepada Ingrid Abdillah dalam

(Ingrid.abdillah@gmail.com).

Wibowo, Agus. 2002. Pendidikan Karakter. Yogyakarta: Pustaka Pelajar.

Widiastuti.2013. Analisis Swot Keragaman Budya Indonesia Jurnal Ilmiah Universitas Darma Persada. Volume 1 Nomor 1 MeiJuni.ISSN 2338-3321.

Winkel \& Hastuti, Sri. 2004. Bimbingan Konseling Diinstitusi Pendidikan. Jakarta: Grasindo. 